\title{
COMMONS IN MARGINAL LANDSCAPES Collective practices for an alternative narrative and use of common spatial resources in peripheral landscapes
}

\author{
Maddalena Ferretti \\ DICEA Department of Civil and Building Engineering, and Architecture, Università Politecnica delle Marche, Italy \\ m.ferretti@univpm.it

\section{Sara Favargiotti} \\ DICAM Department of Civil, Environmental and Mechanical Engineering, Università degli Studi di Trento, Italy \\ sara.favargiotti@unitn.it
}

\begin{abstract}
Questo contributo esplora pratiche di commoning in paesaggi marginali con lo sguardo del progetto - di paesaggio, urbano, di architettura - come speciali forme collettive di trasmissione di valori tangibili e intangibili. I casi studio nelle Alpi e nell'Appennino supportano questa indagine. Nello specifico si analizza il ruolo dei commons con l'obiettivo di capire come queste pratiche nelle aree urbane e rurali possano differire per capacità e forza relazionale, ma siano invece complementari nel facilitare forme di habitat più inclusive. I beni comuni nei paesaggi marginali sono esaminati attraverso le lenti del progetto di paesaggio e d'architettura indagando sfide e dinamiche strutturali ma anche cercando di raccontare una storia alternativa di questi luoghi. Essi necessitano del potenziale innovativo dei commons per promuovere un necessario aggiornamento nella gestione e fruizione delle risorse e degli spazi comuni, siano essi materiali o immateriali.
\end{abstract}

\section{Keywords}

Beni comuni, paesaggi marginali, patrimonio naturale e costruito, progetto di paesaggio, comunità resilienti

\begin{abstract}
This contribution aims to describe commons practices in marginal landscapes from the perspective of the design disciplines - landscape and urban design and architecture - as special collective forms of transfer of tangible and intangible values. Case studies in the Alps and Apennine context support the analysis. Specifically the paper investigates the role of commons to explore how these practices in urban and rural areas can be different for their relational capacity and strength, but are also complementary in enabling forms of inclusive habitat. Commons in marginal landscapes are examined through the lens of landscape design and space transformation to detect structural challenges and dynamics but also to propose an alternative narrative. These places need the innovative potential of commons to steer a necessary upgrade in the management and use of material and immaterial resources.
\end{abstract}

\section{Keywords}

Commons, marginal landscapes, natural and built heritage, regenerative landscape design, resilient communities 


\section{New landscapes of marginality}

While urban areas are growing, contributing to congestion and pollution, other areas of Europe are suffering from steady trends of depopulation and marginalization. More than 60\% of the European population live outside urban contexts (EU 2013). The Strategia nazionale per le Aree interne (Barca et al., 2014) focuses on the marginal territories suffering depopulation dynamics and hosting nearly 13.540.000 inhabitants in Italy. Yet, there are many other marginalized territories that have to tackle with economic stagnation, peripherality, inaccessibility as highlighted by the research Aree interne e dintorni (Marchigiani et al., 2020) that aims to map other peripheral territories outside the conventional 'institutionally-defined' perimeters. The expansion and relevance of the phenomenon of marginality, in its very diverse definitions and multifaceted connotations, makes it crucial to study these contexts and the potential of innovative collective practices, especially with the goal of a possible renaissance and re-settlement of these landscapes.

Municipalities at different scales and in different marginal contexts are operating on common goods as an old/new dimension of public space welfare (Gretter et al., 2018). Beyond unsustainable topdown approaches, a stronger support towards bottom-up initiatives has lately become a more usual governance practice. These initiatives (e.g. ur- ban farming, orchards, flower gardens) boost the idea of common good also as intangible resources for the collective wellbeing and to enact regeneration processes. Framed in a wider strategy and relying on their place-based approach, these actions favor grass-rooted eco-strategies (Spencer, 2014). Often landscape design has been omitted from the strategic and operative discourses. Instead, landscape is meant here as a means of seeing, imagining and controlling territories. It can't be concealed in "a vacuum, outside the context of a real world of productive human relations" (Cosgrove, 1998, p. 2). This interpretation comes from the history of gardening and landscape painting, but the production of the image that legitimizes the relationship between society and nature is still relevant today. Indeed, landscape refers to "human relations in society and place" (Cosgrove, 1998, p. 2) and it represents "a common good uniting us all, without exception" (Unfolding Practice, 2020, p. 184). This relation is more evident in territories where the marginal condition helps to preserve specific landscape features. Landscape thus represents "the shift from land as use to land as exchange in the transition between feudalism and capitalism" (Oloriz, 2020, p. 10). Landscape is embedded in practical uses of the physical world, just like nature and territory. It is produced and not designed. 
chitectural design commons means to have a projective idea for the physical transformation of marginal areas on a basis of innovation and community-led action. Indeed, natural and built heritage are cultural commons (Santagata et al., 2011) as they offer a precious resource to drive sustainable, integrated, and responsible design processes for the regeneration of abandoned urban, peri-urban and rural areas.

The unprecedented conditions emerging from the global crises call for alternative modes of operation for a new world through collective action (Unfolding Practice, 2020). Some commoning experiences show successful multiscalar and interdisciplinary approaches that go in this direction. Estonoesunsolar in Zaragoza is a community-based initiative that transforms unused areas into common spaces. The city-funded program embedded the reintegration of unemployed people into the job market (Grávalos Lacambra, Di Monte, 2021). In Mexico City the Common-Unity project transforms a socially troubled neighborhood. The creation of common landscapes with the reopening of inner courtyards to collective uses has been a first step towards a major social integration, fostering a sense of trust and care for the common space (Montiel, 2015). Reclaiming urban voids to strengthen a sense of community is also a
In Caracas, Lab.Pro.Fab has introduced a self-sufficient social environment based on participation protocols and community (Castro, 2005). Vacant parking lots are transformed with local workers to create a cultural park with artists and activists. Through urban gardening and renaturalization, the area has been reframed with collective spaces and spatial and environmental quality. The highlighted experiences show marginal landscapes that can be found in peripheral contexts (Schroeder et al., 2018), potentially endangered in their commons, which must be regenerated to provide new spaces for different forms of living. How to recover these marginal landscapes for social inclusiveness, and therefore for the community? The Sustainable Development Coals (2015) and the New European Bauhaus (2021) stress the importance of inclusive approaches in landscape and architectural design that can strengthen community identity.

\begin{abstract}
"Landscape practices operate within territorial projects as a political aesthetic technology, and that territory is the lens through which landscapes are designed. Landscape makes up a territorial practice, which, at the same time, shapes and is shaped by the ideological vision produced by landscape" (Oloriz, 2020, p. 9).
\end{abstract}

However, a landscape, without a community who lives, takes care and manages it, can't be considered a landscape.

\section{Landscape design as an agent of commoning}

Landscape design of collective spatial resources can be crucial in envisioning general strategic frameworks to connect otherwise isolated initiatives towards new settlements' constellations. All these initiatives are not indifferent to space. As claimed by Stavrides, "space is not only a product and therefore a stake for commoning but a means of establishing and expanding commoning practices" (2016, p. 4). Through multi-scalar and interdisciplinary strategic approaches, additional sense of belonging and in- 
tangible values can be added to the spatial component, thus engaging with the territorial apparatuses to produce landscapes (Oloriz, 2020). As recalled by Kostakis and Bauwens, designers are the potential protagonists of a 'global commons' society where creativity, innovation and collaboration are the new currency (Kostakis, Bauwens, 2014). The disruptive role of landscape architects and designers can play in favor of a larger collaborative approach with communities towards a more equal and inclusive habitat. Indeed, as James Corner puts it, there is a potentially more meaningful and imaginative relationship that can be developed between ecology, creativity and landscape design that goes beyond "merely ameliorative, compensatory, aesthetic, or commodity oriented" practices (Corner, 1997, p. 82).

A landscape-based strategic approach can foster tangible and intangible values and propose an alternative narrative of common habitat. In Montpellier Coloco works on the survey and recycle of abandoned and underused areas through minimal interventions for the enhancement of biodiversity and the progressive public enjoyment of wastelands. The project detects key places in the city and categorizes them according to their original use and potential through a participatory process (Ferretti, 2016). Similarly, Superkilen in Copenhagen by Topotek1 builds a new landscape carpet in a multi-ethnical neighborhood through a shared process with the residents. People suggest objects coming from their original traditions realising a surrealist collection of global urban diversity. The result is the transformation of this marginal space into a lively, safe, and common place where children play and adults feel at home (BIC et al., 2013). Through the agency of landscape design, people's creativity enables more just and equitable spaces for the community. The Plaza Estacional in Caracas enhances the community's resilience with the architectural and landscape vision. A state-funded linear public space in a former transitional space unveils new opportunities thanks to the landscape intervention and acts as a trigger for further bottom-up actions and common uses (Cox, 2010).

The same landscape-based strategic approach has been at the core of the Rural Commons Festival, an experience co-curated by the authors together with Cristina Dalla Torre and Bianca Elzenbaumer (Dalla Torre et al., 2020). The festival investigated the role of commons in marginal landscapes as a specific condition that differs from urban commons for its relational capacity and strength. The potential of vacant spaces may also apply to rural areas: depopulated villages with empty houses, abandoned agricultural fields with forest colonization are only a few examples of potential spaces for new commons practices. But initiatives on 'rural commons' (Dalla Torre et al., 2021) are often spread episodes that can't count on the relational intensity of urban concentrations. They need different governance and landscape design strategies to be capitalized and enhanced. In this sense the following strategic visions display networking possibilities and alternative narratives that can support administrations and communities in the transformation and adaptation of their habitats towards more circular and open public spaces.

\section{Case studies: two marginal landscapes in the re- gions of Marche and Trentino}

The selected case studies show how commons practices could effectively trigger more resilient territorial futures. Two marginal landscapes, in the Apennine in the Marche region and the Alps in Trentino, are the test-fields to investigate the capacity of landscape design to generate shared actions with local communities, to intervene at different scales, to favor common perception, use, and management of space and to ease a different perspective on urban-rural territories. The two experimental experiences share similar economic, social, and territorial backgrounds but are exposed to differ- 


\section{Marche strategic and visioning approach}

In the South of Marche region, inner areas on the Apennine mountains have been affected by the tragic seismic events of 2016.

The earthquake was an accelerator of pre-conditions of structural decline and abandonment. Almost five years after the emergency these contexts are still lacking a clear perspective for their future as there is no obligation for the municipalities to adopt a strategic vision (Marinelli et al., 2021). Through research by design we envisaged new development paths in close collaboration with local actors, linking the necessary reconstruction steps to a strategic landscape framework able to comprehend isolated practices of collective resources management. The extremely valuable but highly endangered heritage of small villages is thought as a new common space to be reactivated through landscape design, thus becoming a fundamental asset to recreate a feeling of belonging. The strategic landscape framework was articulated in a systemic vision that devised integrated and transcalar transformation processes, ranging from the landscape to the architectural scale. The vision focuses on border territories, marginal landscapes between the flatlands and the mountains,
Sibillini mountains that is a threshold but also a space of interface and a gateway.

This landscape system is complementary to the Sibillini Natural Park, to the productive river valleys running towards the Adriatic coastline, and to the touristic and religious paths of the pilgrims (fig. 1). The vision proposes a hyper-connected territory where accessibility and cooperation are prior goals (fig. 2). The collective dimension is reflected in design approaches that tried to recycle and adapt some village common spaces to turn them into innovative places for the community. The proposed landscape interventions on the open spaces of the hamlets confront the predominant rhetoric of underdeveloped and slow territory with a new imaginative and narrative potential. Landscape and architectural design is addressed to regenerate squares, recycle damaged buildings, and introduce new uses to recover traditional values (fig. 3), as well as to strengthen resilient and collective approaches. In the Marche case study, the landscape framework provided the general vision for the regeneration of open spaces and architectures, highlighting the need for more sustainable public spaces and the integration of intangible values in design processes.

\section{Trentino collective and 'instinctive' design ap- proach}

The Terragnolo Valley, in the North-East of Rovereto (TN), in the Alpine mountains of Trentino, is a spread municipality characterized by scattered hamlets and an impressive nature for an extension of almost $13 \mathrm{~km}$ with a total of 706 inhabitants (2019). Here, the marginal landscape can be a resource to repositioning 'forgotten' places in the collective imagination and rediscover - thanks to physical micro-intervention and social engagement - an innovative connection between natural and human landscapes (fig. 4). All this produces forms of resistance that the contribution intends to study and narrate visually. 


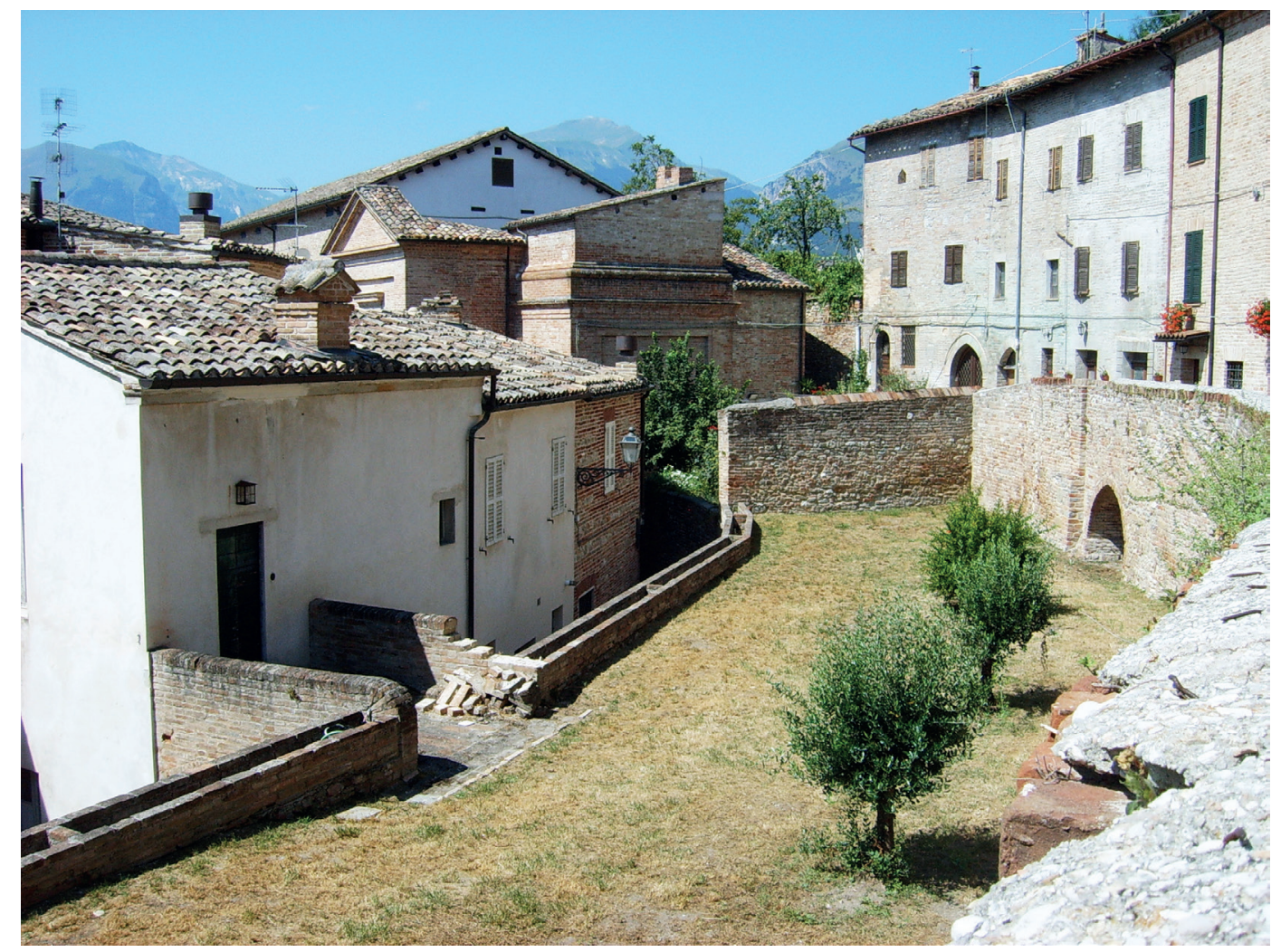

Fig. 1 -Terraced landscapes in the historical centre of Amandola (FM), Photo M. Ferretti, 2018. 


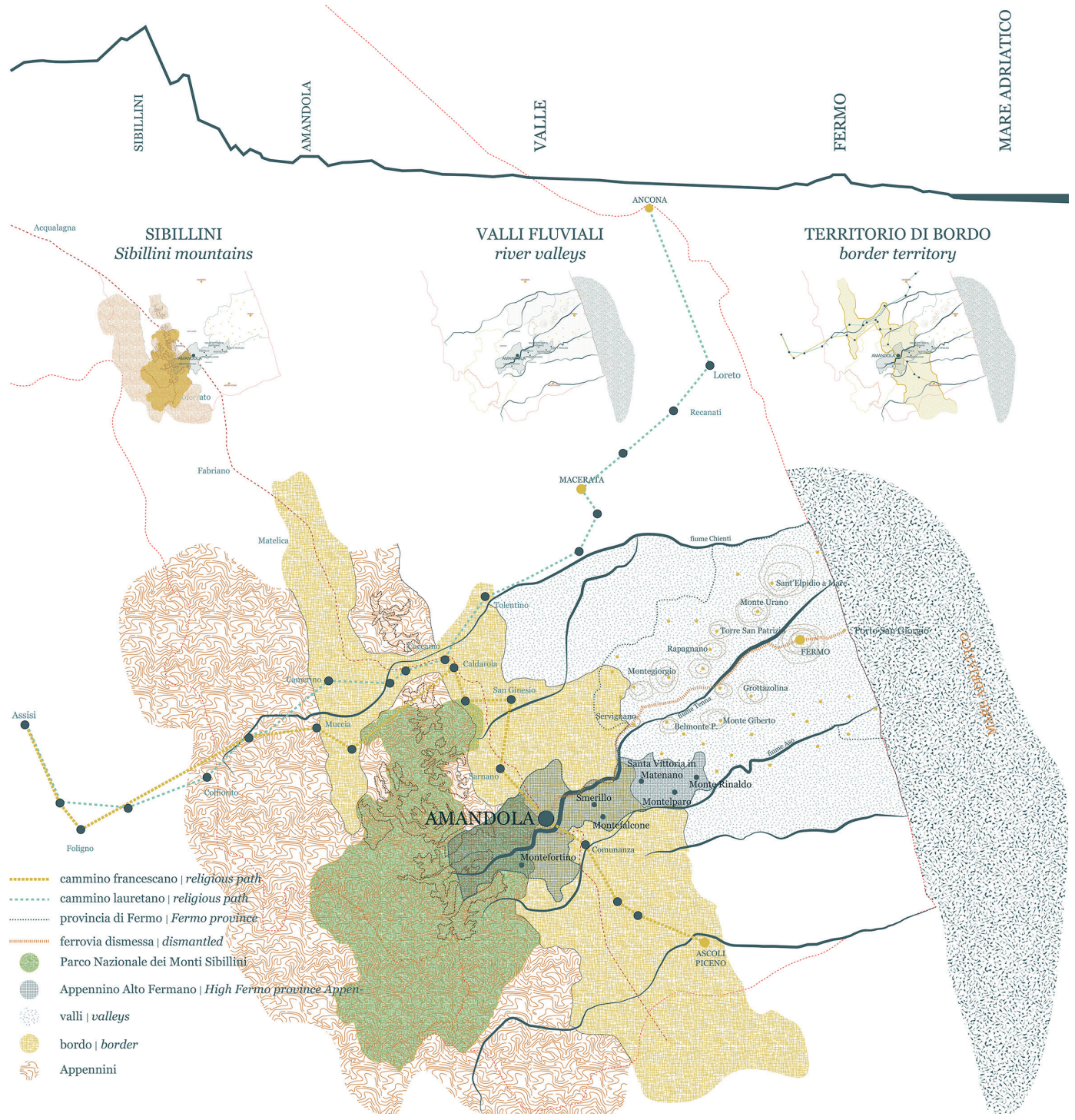

Fig. 2 -Landscape and territorial strategies for the earthquake marginal landscapes in the Marche Region. M. Ferretti, F. Chiacchiera for Living with Earthquakes, DICEA, UNIVPM. 

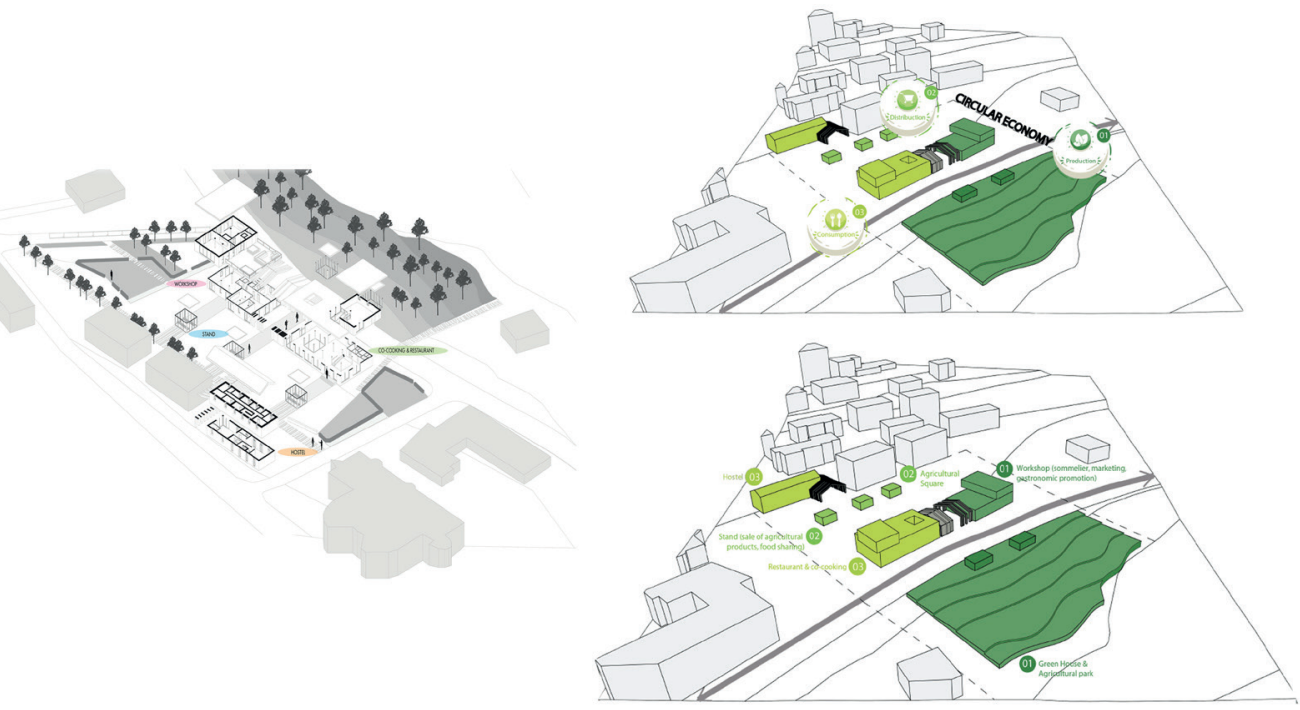

Fig. 3 - Agripiazza, design research for the regeneration and renaturalization of the former railway station in Amandola (FM). E. Palandra, S. Rosa, E. Vicarelli for Open Heritage (M. Ferretti), DICEA, UNIVPM.

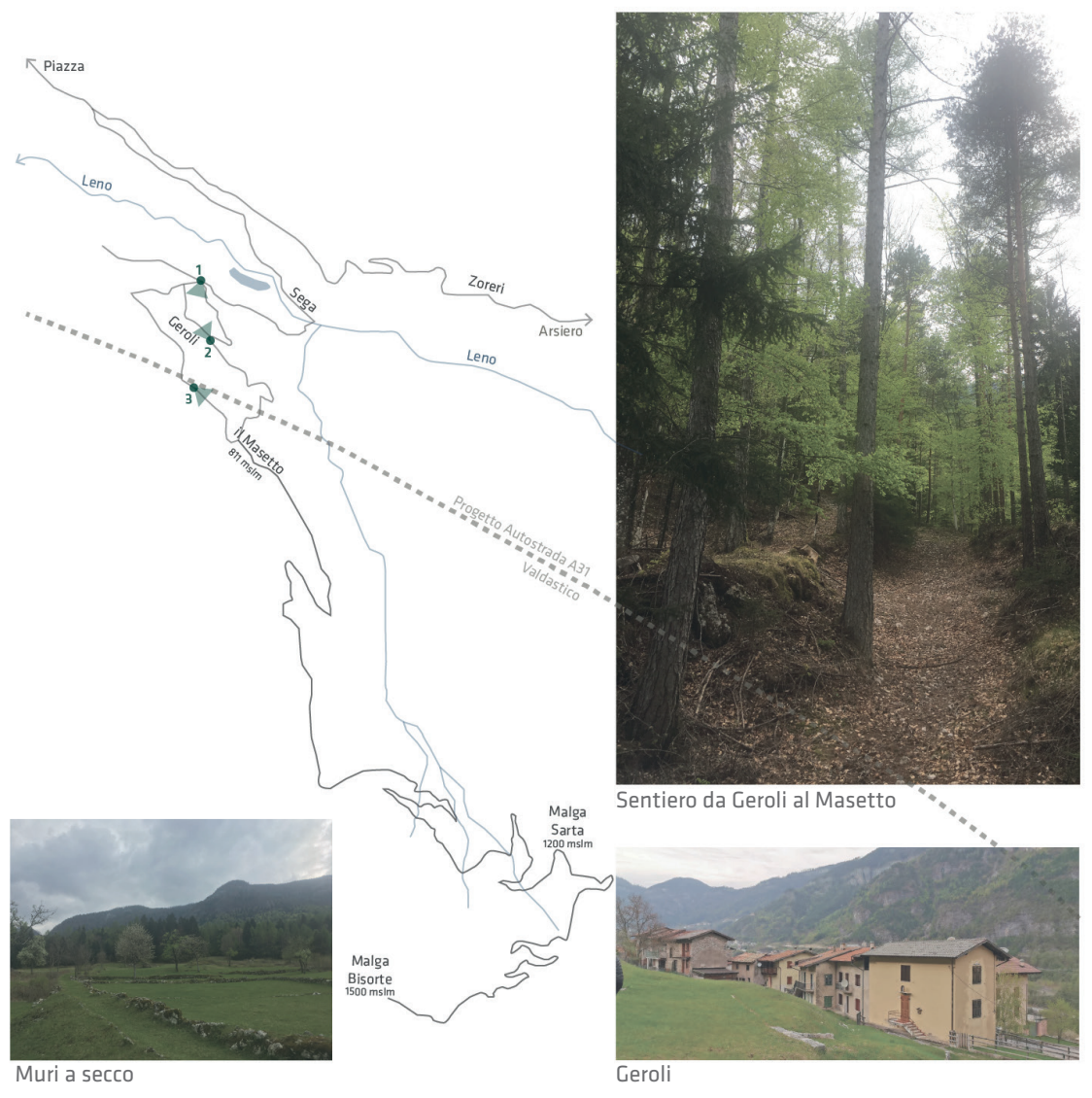

Fig. 4 - The landscape features in Geroli, one of the 33 hamlets in the Terragnolo valley.

Collage by Chiara Frungillo, Martin Marchiori and Diego Duarte for Vertigo Workshop, DICAM, UNITN, 2019. 

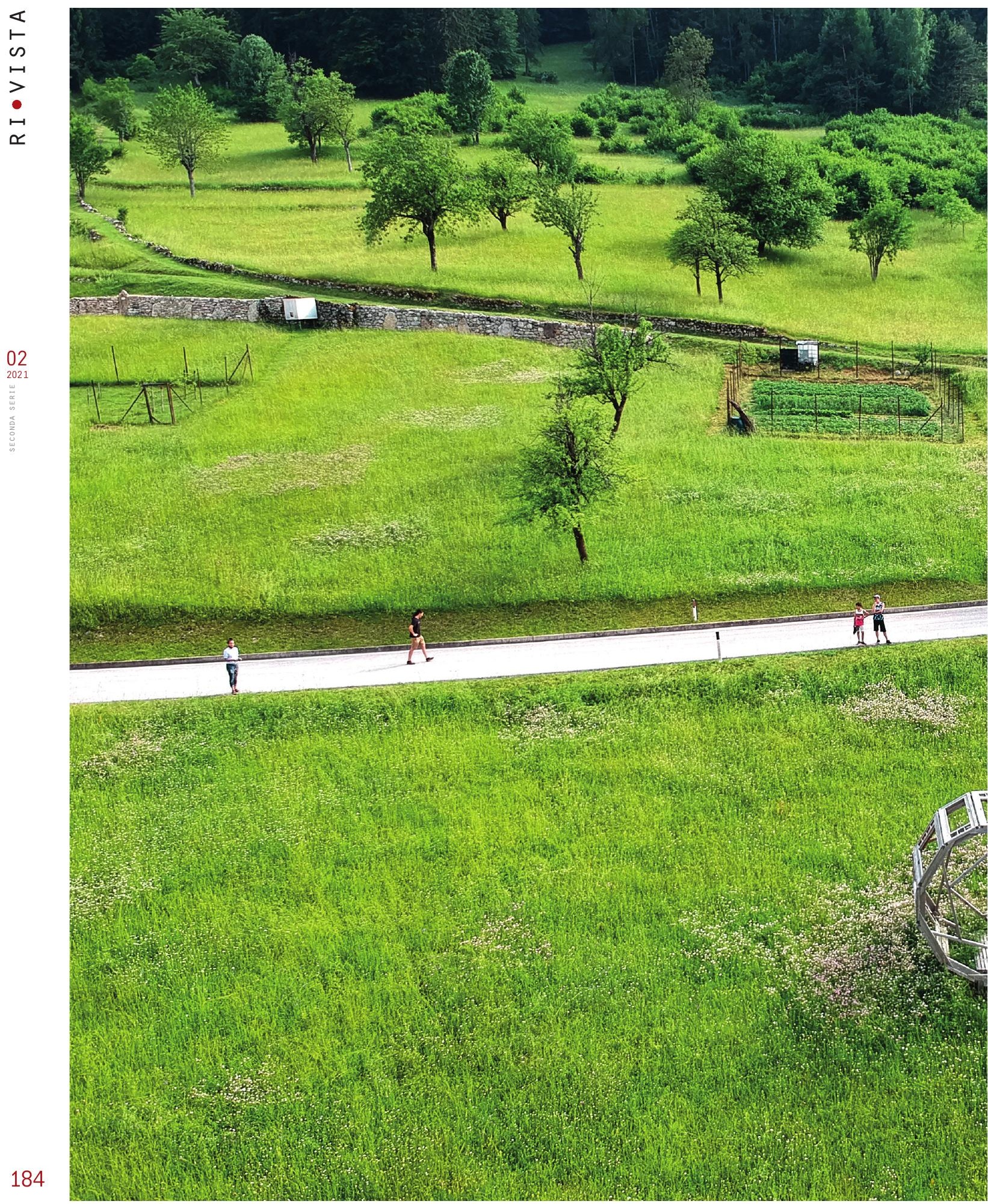

Fig. 5 - The wheel is thought of as an artistic installation but also as a lens to experiences through the landscape,

Camposaz 2019 (ph. Nicole Faiella, 2021) 
The collective design and construction workshop held by Camposaz in July 2019 and 2021 in Geroli has been a transdisciplinary experimental laboratory of sensitive narration and production with the aim of witnessing, telling, designing and acting in a moment of transformation of the territory, questioning on the Terragnolo valley, about what it no longer is, what it is, and what it could be. Four temporary interventions strongly connected to the social, emotional and physical landscape of the hamlets and new terraced walls have been built (fig. 5). Camposaz is an 'instinctive architectural practice' with a collaborative improvisation approach where the human scale is conceived as the specific scale to be addressed. Among other self-construction national and international initiatives, the real value of Camposaz does not lie solely in the architectural quality and construction of the realized artifacts, but especially in the intense experience of involvement that is created between participants and inhabitants throughout the design process. This approach recalls "Cosgrove's idea of landscape as a form of 'engagement of the human subject with the material object' that is collectively built'; and, thus, both 'subject and object of human agency'" (Oloriz, 2020, p. 15). In this framework, the design experience in Terragnolo worked as an enabler of new processes of involvement and co-design with the local community and it rooted temporary actions as the premise for long-term social impacts in the valley. Indeed, the workshop became the opportunity to test instant actions to design and construct with human and natural features, with the aim of verifying the progressive effects of the process - usually linked to the temporariness of the experience and the duration of the events - within a 'permanent' community (fig. 6). These experiences help to reflect on how to invert conventional assumptions about marginal landscapes: perhaps it is the world outside Terragnolo that should learn to 'depopulate' visibility and marketing, and regaining the ability to see and listen to what surrounds it. Placing a soft and sensitive gaze on the territory of Terragnolo offered the opportunity to share and learn something, by absorbing a little silence, a little slowness, a little simplicity.

\section{Final considerations}

The reflections and cases presented above show that inclusive engagement of local communities through commoning practices can unveil new dynamics of transformation and innovation in marginal landscapes. Local knowledge and participation can produce new values but also social and spatial safeguard reducing the risk of abandonment, strengthening landscape care, community empowerment and project accountability. Providing common spaces and services grounded in local participation and based upon symbiotic relationships with earth-others offers an alternative paradigm for a more equitable, economical, and environmentally sound habitat. This approach tries to go beyond conventional indicators of growth and development, according to which well-being is measured by the level of population increase, or by the attractiveness and popularity of a place, whereas depopulation is described as a pathology, a condition to be cured. In this alternative view, time is a key factor: slowing down, observing, and imagining become crucial actions for the regeneration of the territory. 'Slowness' is intended as the attitude to see things we otherwise wouldn't perceive because it is strongly connected to the latin etymological root of the word 'care' (ku-/kav') which means to observe, to utilize observation with consciousness and to take the responsibility derived from it (Pileri, 2020). Commoning unveils the uniqueness of the context, the landscape features and the specific relationship between natural and built heritage. A 'community of communities' would strengthen networked spatial constellations to implement in- 


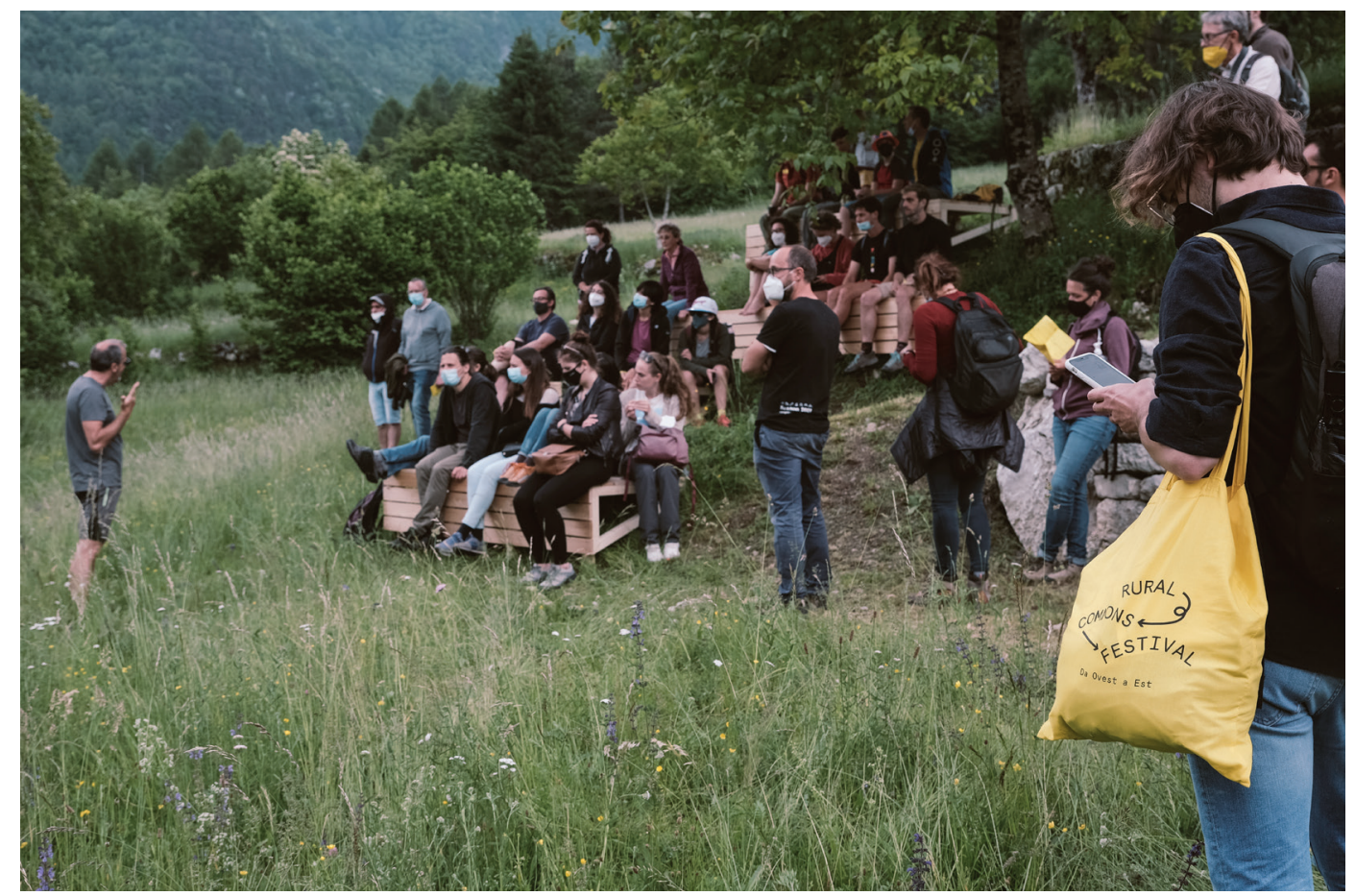

Fig. 6 - The Parliament of the Community by Camposaz in the terraced landscape of Ceroli during the Rural Commons Festival (ph. Marco Rauzi, 2021).

novative regeneration, transformation, and adaptation strategies. The importance of considering the spatial resource in the definition of commons is quite evident, as space is where new actions can happen. At the same time, landscape design is also a crucial player not only for its inventive capacity, but also as it can direct the strategic and operative goals of these contexts. Therefore, there is even more need to find new ways of production of public space, prioritizing community-led initiatives to enhance immaterial values, traditions, and identities.

The landscape-based strategic approaches described in this contribution are based on the idea of circularity of material and immaterial resources - such as the recycling of abandoned buildings or the recovery of traditions - to give rise to new community economies. This might lead to a multiplication effect that can increase the positive im- pact at local scale towards more sustainable and resilient landscapes. To avoid the risk for commoning practices to be isolated actions, it is necessary to strengthen networks and spread the collaboration among a plurality of actors (e.g. public institutions, private entrepreneurs, associations, individuals): interdependence (Miller and Gibson-Graham, 2019) of people, ideas, practices, and resources can drive local policies for landscape care and heritage regeneration. In this sense landscape design can be a tool to change the perception, narrative, and perhaps the transformation capacity of commons to reimagine more sustainable, interconnected and inclusive habitats. 


\section{Bibliografia}

Barca F., Casavola P., Lucatelli S. (eds) 2014, Strategia nazionale per le Aree interne: definizione, obiettivi, strumenti e governance, n. 31, Materiali Uval, Roma, <https://www. agenziacoesione.gov.it/wp-content/uploads/2020/07/ MUVAL_31_Aree_interne.pdf> (04/2021).

Bertacchini E., Bravo G., Marrelli M., Santagata W. 2012, Defining Cultural Commons, in E. Bertacchini, G. Brav, M. Marrelli, W. Santagata (eds), Cultural Commons. A New Perspective on the Production and Evolution of Cultures, Edward Elgar Publishing.

BIG Bjarke Ingels Group, Superflex, Topotek 12013 , Superkilen, Copenhagen, <https://landezine.com/urban-revitalization-superkilen-by-topotek1-big-superflex/> (10/2021).

Camposaz 2017, About Camposaz, <https://www.camposaz.com/aboutus/> (06/2021).

Castro M. 2005, Tiuna el Fuerte Foundation, <https://landscapeasurbanismamericas.net/tiuna-el-fuerte-foundation/> (10/2021).

Corner J. 1997, Ecology and Landscape as agents of creativity, in G. Thompson, F. Steiner (eds), Ecological Design and Planning, Wiley, New York.

Corner J. 1999, The agency of mapping: Speculation, critique, and invention, in D. Cosgrove (ed.), Mapping, Reaktion, London.

Cosgrove D. 1998, Social Formation and Symbolic Landscape, University of Wisconsin Press, Madison.

Cox A. 2010, Plaza Estacional <https://landscapeasurbanismamericas.net/plaza-estacional/> (10/2021).

Dalla Torre C., Elzenbaumer B., Favargiotti S., Ferretti M. (2021), Towards a Rural Commons Manifesto. Investigating emerging commoning practices, engaging communities, ex- ploring design approaches through an itinerant and transregional Festival, in 60th ERSA Congress "Territorial Futures. Visions and scenarios for a resilient Europe", <https://ersa. org/events/60th-ersa-congress-2/> (06/2021).

Dalla Torre C., Elzenbaumer B., Favargiotti S., Ferretti M. 2020, Rural Commons Festival, <https://www.ruralcommonsfestival.com/about-rural-commons-festival> (05/2021).

Delsante I., Bertolino, N. 2017, Urban spaces' commoning and its impact on planning. A case study of the former slaughterhouse exchange building in Milan, «Der öffentliche Sektor - The Public Sector», n. 43, pp. 45-56.

European Union 2013, Eurostat Regional Yearbook 2013, Publications Office of the European Union, Luxembourg, <https://ec.europa.eu/eurostat/documents/3217494/5784301/KS-HA-13-001-EN.PDF> (05/2021).

European Union 2021, The New European Bauhaus, <https://europa.eu/new-european-bauhaus/index_en> (03/2021).

Ferretti M. 2016, Land Stocks. New operational landscapes of city and territory, LISt Lab, Trento-Barcelona.

Georgieff P. 2018, Poetica della Zappa. L'arte collettiva di coltivare i giardini, Deriveapprodi, Roma.

Gretter A., Rizzi C., Favargiotti S., Betta A., Ulrici G. 2018, Trento Social Commons. Community Engagement as Tools for Physical and Cultural Relationships Between Rural and Peripheral Spaces, «Journal of Alpine Research | Revue de géographie alpine», n. 106-2, pp. 1-14, <http://journals. openedition.org/rga/4166> (04/2021).

Kostakis V., Bauwens M. 2014, Network Society and Future Scenarios for a Collaborative Economy, Basingstoke. 
Marchigiani E., Perrone C., De Vita G. E. 2020, Oltre il Covid, politiche ecologiche territoriali per aree interne e dintorni. Uno sguardo in-between su territori marginali e fragili, verso nuovi progetti di coesione, «Working papers. Rivista online di Urban@it», n. 1/2020, pp. 1-9, <https://www.urbanit.it/wp-content/uploads/2020/07/BP_Marchiggiani_Perrone_DeVita.pdf> (06/2021).

Marinelli G., Vitillo P., Galuzzi P., Domenella L. 2021, Territori fragili in transizione: Strategie, strumenti, metodi applicati nel processo di ricostruzione post sisma, in Atti della XXIII Conferenza Nazionale SIU - Società italiana degli Urbanisti, "DOWNSCALING, RIGHTSIZING. Contrazione demografica e riorganizzazione spaziale", Torino 17-18 Giugno 2021, Vol. 4, pp. 108-122, <http://media.planum.bedita.net/ea/b8/ Atti\%20XXIII\%20Conferenza\%20Nazionale\%20SIU_Torino_VOL.04_Planum\%20Publisher_2021.pdf> (06/2021).

Miller E., Gibson-Graham J. K. 2019, Thinking with interdependence: from economy/environment to ecological livelihoods, in J. Bennett, M. Zournazi (eds), Thinking in the World, Bloomsbury, New York.

Montiel R. 2015, Common-Unity<https://landezine.com/ common-unity-by-rozana-montiel/> (10/2021).

Oloriz C. 2019, Landscape as Territory: A Cartographic Design Project, Actar Publisher \& Architectural Association, New York, Barcelona.

Ostrom E. 1990, Governing the Commons: The Evolutions of Institutions for Collective Actions, Cambridge University Press, New York.

Pileri P. 2020, Progettare la lentezza, People, Busto Arsizio (VA).

Santagata W., Bertacchini E., Bravo G., Marrelli M. 2011, Cultural Commons and Cultural Communities, in: Sus- taining Commons: Sustaining Our Future, the Thirteenth Biennial Conference of the International Association for the Study of the Commons, conference paper, Hyderabad, India, 10-14 January 2011, pp. 1-14, <https://dlc.dlib.indiana.edu/dlc/bitstream/handle/10535/7359/297.pdf?sequence $=1$ \&isAllowed $=y>(05 / 2021)$.

Spencer D. 2014, Nature is the dummy: circulations of the metabolic, in D. Ibañez, N. Katsikis (eds) New Geographies 6: 'Grounding Metabolism', Harvard University Press.

Stavrides S. 2016, Common Space: the City as Commons, London.

Schröder J., Carta M., Ferretti M., Lino B. (eds) 2018, Dynamics of Periphery. Atlas for Emerging Creative Resilient Habitats, Berlin.

Unfolding Practice, 2020, Unfolding Practice. A guerilla curation collaboration, in \&beyond collective (eds) Archifutures Volume 6. 'Agency', dpr-barcelona, Barcelona, $<$ https://futurearchitecturelibrary.org/archifutures-articles/volum-6-agency/unfolding-practice-guerilla-curation-collaboration/> (10/2021).

United Nations 2015, The 17 Sustainable Development Goals, <https://sdgs.un.org/goals> (03/2021).

United Nations General Assembly 2016, New Urban Agenda, United Nations, New York, <http://habitat3.org/thenew-urban-agenda> (03/2021).

Varotto M. 2020, Montagne di mezzo. Una nuova geografia, Piccola Biblioteca Einaudi, Milano. 